\title{
Bibliography of Works by Lord Kames and Abbreviated References
}

\author{
1 The Editions of Lord Kames's Principal Works Referred to and the \\ Abbreviations of References in this Book
}

There is no critical edition of Lord Kames's works. However, what comes closest to one is the recent publication of some of Kames's major works in the Natural Law and Enlightenment Classics series of the Liberty Fund (Indianapolis) from 2005 onwards. There are also some modern facsimile reprints which are available in most libraries, and, as a great improvement for researchers on Kames, there is online availability of all of Kames's works (in several editions) on the Eighteenth Century Collections Online database (http://gale.cengage.co.uk). Kames frequently revised his works considerably for subsequent editions, but since these changes are in most cases insubstantial, reference has normally been made to the last editions which were published during his lifetime or corrected by him, if published posthumously. A separate additional reference will be given in the book where, exceptionally, another edition has been consulted. Otherwise, the following editions of Kames's principal works and abbreviations of references have been used:

Henry Home (later: Lord Kames) (1732), Essays Upon Several Subjects in Law, Edinburgh: R. Fleming \& Company.

Abbreviated reference: ESL (for example: ESL, p. 1: Jus Tertii).

Henry Home (later: Lord Kames) (1993), Essays Upon Several Subjects Concerning British Antiquities, with a New Introduction by John V. Price, London: Routledge/Thoemmes Press.

Abbreviated reference: EBA (for example: EBA II, p. 27 = essay 2, p. 27: Constitution of Parliament).

This is a facsimile edition of the second edition, London 1749 (1st edn 1747).

Henry Home, Lord Kames (2005), Essays on the Principles of Morality and Natural Religion, ed. and with an introduction by Mary Catherine Moran, Indianapolis: Liberty Fund. 
Abbreviated reference: PMR (for example: PMR 1, II, iii, p. 30 = part 1, essay 2, chapter 3, p. 30: Duty and Obligation).

This edition is based on the third edition, Edinburgh 1779 (1st edn 1751, 2nd edn 1758).

Henry Home, Lord Kames (1792), Historical Law-Tracts, Fourth Edition. With Additions and Corrections, Edinburgh: Cadell, Bell \& Bradfute, Creech (1st edn 1758).

Abbreviated reference: HLT (for example: HLT III, p. $88=\operatorname{tract} 3$, p. 88 : Property).

Henry Home, Lord Kames (2011), Principles of Equity, Volumes 1 and 2, with a New Introduction by Andreas Rahmatian, Clark, New Jersey: The Lawbook Exchange.

Abbreviated reference: PE (for example: PE I, i, 4, p. (1) 194 = book 1, part 1, chapter 4, p. 194 (in volume 1 [of two volumes]): Powers of a court of equity to remedy what is imperfect in common law with respect to deeds and covenants). This is a facsimile edition of the third edition, Edinburgh 1778 (1st edn 1760, 2nd edn 1767).

Henry Home, Lord Kames (2005), Elements of Criticism, vols 1 and 2, ed. and with an Introduction by Peter Jones, Indianapolis: Liberty Fund.

Abbreviated reference: EC (for example: EC I, 3, p. $141<(1) 241>=$ volume 1, chapter 3, p. 141 (p. 241 in volume 1 [of three volumes] of the original first edition): Beauty).

This 2005 edition is based on the posthumous sixth edition, Edinburgh 1785 (1st edn 1762, 2nd edn 1763, 3rd edn 1765, 4th edn 1769, 5th edn 1774). The additional page reference $[<>]$ is given for the first edition of 1762 (Elements of Criticism (1762), in Three Volumes, Edinburgh: A. Millar, A. Kincaird \& J. Bell) because the first edition tends to be more widespread than the sixth edition of 1785 in its original publication, especially because of its 1970 facsimile reprint (Elements of Criticism, 1970, with an Introduction by Robert Voitle, Hildesheim and New York, Georg Olms Verlag). The text of the sixth edition is printed in the modern 2005 edition which is always stated first.

Henry Home, Lord Kames (2007), Sketches of the History of Man, Books I, II, III ( 4 vols in 3 books), ed. and with an Introduction by James A. Harris, Indianapolis: Liberty Fund.

Abbreviated reference: SK (for example: SK I, iii, p. $74<127>=$ book 1 , sketch 3, p. 74 [p. 127 of the original third edition]: Origin and Progress of Commerce).

This edition is based on the posthumous third edition, Edinburgh 1788 (1st edn 1774, 2nd edn 1778; besides, editions published in Dublin and (in part) Philadelphia).

The additional page reference $[<>]$ is given to the original third edition of 
1788 (issued in four volumes) because the third edition is often available in libraries.

Henry Home, Lord Kames (1993), Elucidations Respecting The Common and Statute Law of Scotland, with a New Introduction by John V. Price, London: Routledge/Thoemmes Press.

Abbreviated reference: EL (for example: EL, art. 11, p. 76 = article 11, p. 76 : Dominium directum et utile).

This is a facsimile edition of the first edition, Edinburgh 1777 (2nd edn 1800).

\section{Other Works by Lord Kames (not in abbreviated reference)}

These are cited in the text in the same way as any other literature, with author, short title (if necessary), year, page number, for example: Kames, Introduction to the Art of Thinking (1993a: 57).

Books

Home, Henry, Lord Kames (1766), Progress of Flax-Husbandry in Scotland, Edinburgh: Sands, Murray and Cochran.

Home, Heinrich (1775), Versuche über die Geschichte des Menschen. Aus dem Englischen übersetzt [von Anton Ernst Klausing]. Volumes 1 and 2, Leipzig: Johann Friedrich Junius.

This is the Leipzig edition of the German translation of the first edition of Kames's Sketches of the History of Man.

Home, Henry, Lord Kaims [sic] (1776), Six Sketches on the History of Man, Philadelphia: R. Bell and R. Aitken.

This is the 'Philadelphia' edition (the first edition in the US). In the full Scottish edition of the Sketches of the History of Man of 1774 (1st edn), the equivalent is: book 1, Preliminary Discourse, and sketches 1, 2, 3, 4 and 6.

Home, Henry, Lord Kames (1776), The Gentleman Farmer. Being an Attempt to improve Agriculture by Subjecting it to the Test of Rational Principles, Edinburgh: W. Creech and T. Cadell.

Home, Heinrich (1790), Versuche über die Geschichte des Menschen. Aus dem Englischen übersetzt [von Anton Ernst Klausing]. Volumes 1-3, Wien: F. A. Schrämbl.

This is one of the (incomplete, possibly partly censured) Vienna editions of the German translation of the first edition of Kames's Sketches of the History of Man.

Home, Henry, Lord Kames (1799), Select Decisions of the Court of Session from the year 1752 to the year 1768. Collected by the Honourable Henry Home of Kames, one of the Senators of the College of Justice, 2nd edn, Edinburgh: printed for Bell $\&$ Bradfute (1st edn 1780). 
Home, Henry, of Kames (1861), Elements of Criticism; revised, with omissions, additions, and a new analysis, ed. Rev. James R. Boyd, New York: A. S. Barnes $\&$ Burr.

This is a 'purged' edition in the United States of Kames's Elements of Criticism to secure its 'adoption as a text-book, especially in female seminaries'.

Home, Henry, Lord Kames (1993a), Introduction to the Art of Thinking, with a new Introduction by John V. Price, London: Routledge/Thoemmes Press.

This is a facsimile edition of the third edition, Edinburgh 1775 (1st edn 1761, 2nd edn 1764, 4th edn 1789).

Home, Henry, Lord Kames (1993b), Loose Hints upon Education, Chiefly Concerning the Culture of the Heart, with a new Introduction by John V. Price, London: Routledge/Thoemmes Press.

This is a facsimile edition of the second edition, Edinburgh 1782 (1st edn 1781).

Articles and pamphlets

Home, Henry, Lord Kames (1754), 'Of the Laws of Motion', in Essays and Observations, Physical and Literary. Read before a Society in Edinburgh, and published by them, vol. 1, article 1, Edinburgh: G. Hamilton and J. Balfour, pp. 1-69.

Home, Henry, Lord Kames (1797), An Essay on the Hereditary and Indefeasible Right of Kings. Composed in the Year 1745, Edinburgh: Thomas Maccliesh.

\section{Unpublished Material by Lord Kames}

'Dependence of Mathematics and Physics on Logic. Comments to the Philosophical Society by Ld Kaims' [sic], undated (National Archives of Scotland, no. GD 24/3/472), manuscript.

Letter by Henry Home to Samuel Clarke (five pages, not dated), and reply letter from Samuel Clarke to Henry Home (three pages, 29 August 1723) (National Archives of Scotland, no. GD24/1/548-1 and 2). 
Indigence and obscurity are the parents of industry and oeconomy: These, of riches and honour: These, of pride and luxury: These, of sensuality and idleness; and these, of indigence and obscurity. Such are the revolutions of life.

Difference in opinion is no less natural than difference in look: It is at the same time the very salt of conversation. Why then should we be offended at those who think differently from us?

(Henry Home, Lord Kames, Introduction to the Art of Thinking (1761), pp. 2, 68) 
